\title{
Repeated Cocaine Administration Decreases Calcineurin (PP2B) but Enhances DARPP-32 Modulation of Sodium Currents in Rat Nucleus Accumbens Neurons
}

\author{
Xiu-Ti Hu*,', Kerstin Ford' and Francis J White' \\ 'Department of Cellular and Molecular Pharmacology, Chicago Medical School, Rosalind Franklin University of Medicine and Science, North \\ Chicago, IL, USA
}

\begin{abstract}
Our previous studies have demonstrated that repeated cocaine (COC) administration reduces voltage-sensitive sodium and calcium currents ( $I_{\mathrm{Na}}$ or VSSCs and $I_{\mathrm{Ca}}$ or VSCCs, respectively) in medium spiny nucleus accumbens (NAc) neurons of rats. The present findings further indicate that chronic COC-induced $I_{\mathrm{Na}}$ reduction in NAc neurons is regulated by decreased dephosphorylation and enhanced phosphorylation of $\mathrm{Na}^{+}$channels. Whole-cell voltage-clamp recordings revealed that dephosphorylation of $\mathrm{Na}^{+}$channels by calcineurin $(\mathrm{CaN})$ enhanced $I_{\mathrm{Na}}$, while inhibition of protein phosphatase I (PPI) by phosphorylated dopamine- and cAMP-regulated phosphoprotein $\left(M_{r}=32 \mathrm{kDa}\right)$ (DARPP-32) at the site of threonine 34 ( $p$-Thr.34-DARPP-32) suppressed $I_{\text {Nar }}$, in freshly dissociated NAc neurons of saline-pretreated rats. However, the effects of $\mathrm{CaN}$ on enhancing $I_{\mathrm{Na}}$ were significantly attenuated, and the action of P-Thr.34-DARPP-32 to decrease $I_{\mathrm{Na}}$ was mimicked, although not potentiated, by repeated COC pretreatment. Dephosphorylation of $\mathrm{Na}^{+}$channels by PPI also enhanced $I_{\mathrm{Na}}$, but this effect of PPI on $I_{\mathrm{Na}}$ was not apparently affected by repeated COC administration. Western blot analysis indicates that the protein levels of CaN and DARPP-32 were significantly decreased and increased, respectively, while the PPI levels were unchanged, in the COC-withdrawn NAc as compared to saline-pretreated controls. Combined with previous findings, our results indicate that both $\mathrm{CaN}$ and PPI modulate the increase in / Na via enhancing dephosphorylation, while p-Thr.34DARPP-32 reduces $I_{\mathrm{Na}}$ by inhibiting PPI-induced dephosphorylation, thereby stabilizing the phosphorylation state, of $\mathrm{Na}^{+}$channels in NAc neurons. They also suggest that chronic $\mathrm{COC}$-induced $I_{\mathrm{Na}}$ reduction may be attributed to a reduction in $\mathrm{Ca}^{2+}$ signaling, which disrupts the physiological balance of phosphorylation and dephosphorylation of $\mathrm{Na}^{+}$channels.

Neuropsychopharmacology (2005) 30, 916-926, advance online publication, 23 February 2005; doi:I0.1038/sj.npp. I 300654
\end{abstract}

Keywords: cocaine (COC); calcineurin (CaN); DARPP-32 (dopamine- and cAMP-regulated phosphoprotein; $M_{r}=32 \mathrm{kDa}$ ); $\mathrm{Ca}^{2+}$; nucleus accumbens (NAc); voltage clamp; Western blot

\section{INTRODUCTION}

The nucleus accumben (NAc) is a forebrain region functionally involved in addiction and withdrawal effects of cocaine (COC) (Hyman, 1996; White and Kalivas, 1998). Repeated $\mathrm{COC}$ administration reduces the membrane excitability of NAc neurons via suppressing $I_{\mathrm{Na}}$ and $I_{\mathrm{Ca}}$ but enhancing $I_{\mathrm{K}}$ (Zhang et al, 1998, 2002; Hu et al, 2004). However, the mechanism underlying COC-induced changes in ion channel function is unknown. Recent findings

\footnotetext{
*Correspondence: Dr X-T Hu, Department of Cellular and Molecular Pharmacology, Chicago Medical School, Rosalind Franklin University of Medicine and Science, 3333 Green Bay Road, North Chicago, IL 60064-3095, USA, Tel: + I 847578 8663, Fax: + I 8475783268 , E-mail: xiu-ti.hu@rosalindfranklin.edu

Received 3 August 2004; revised 12 November 2004; accepted 15 November 2004

Online publication: 17 November 2004 at http://www.acnp.org/citations/ NPPI | | 704040352/default.pdf
}

suggest that alterations in phosphorylation and dephosphorylation of voltage-sensitive $\mathrm{Na}^{+}$channels may contribute to the COC-induced decrease in $I_{\mathrm{Na}}$. It is well established that $\mathrm{Na}^{+}$channels are under dynamic control of phosphorylation/dephosphorylation (Greengard et al, 1999; Schiffmann et al, 1998), in which calcineurin (CaN), $\mathrm{a} \mathrm{Ca}^{2+}$, calmodulin-dependent serine/threonine protein phosphatase (also known as protein phosphatase 2B, PP2B), plays a significant role (see Catterall, 1997; Yakel, 1997; Herzig and Neumann, 2000; Greengard, 2001; Shibasaki et al, 2002 for a review). For instance, while cAMP-dependent protein kinase A (PKA) phosphorylates $\mathrm{Na}^{+}$channels, which leads to a decrease in $I_{\mathrm{Na}}$ (Li et al, 1992; Cantrell et al, 1999; Smith and Goldin, 1997), CaN dephosphorylates specific serine sites in the intracellular loop of type II-A $\alpha$ subunit of $\mathrm{Na}^{+}$ channels (Murphy et al, 1993) and enhances $I_{\mathrm{Na}}(\mathrm{Hu}$ et al, 2005). Although PKA-activated p-Thr.34-DARPP-32 reduces $I_{\mathrm{Na}}, \mathrm{CaN}$ inhibits this action of p-Thr.34-DARPP-32 (Greengard et al, 1999; Schiffmann et al, 1998). However, 
the functions of PKA and $\mathrm{CaN}$ are enhanced and may be reduced, respectively, after chronic exposure to COC (Terwilliger et al, 1991; Zhang et al, 2002; Hu et al, 2004).

Previous investigations have demonstrated that chronic COC treatment decreases $I_{\mathrm{Ca}}$ (Zhang et al, 2002; Hu et al, 2004). On the other hand, both PKA and $\mathrm{CaN}$ regulate $\mathrm{Ca}^{2+}$ signaling via phosphorylation and dephosphorylation of inositol 1,4,5-triphosphate receptors ( $\left.\mathrm{IP}_{3} \mathrm{Rs}\right)$, which would induce a decrease (Supattapone et al, 1988; Ferris et al, 1991; Quinton and Dean, 1992; Tertyshnikova and Fein, 1998; but also see Volpe and Alderson-Lang, 1990; Tang et al, 2003), and possible increase (Cameron et al, 1995, 1997), in $\mathrm{IP}_{3} \mathrm{R}$-mediated $\mathrm{Ca}^{2+}$ release, respectively. In contrast, inhibition of CaN not only facilitates PKA-induced phosphorylation of $\mathrm{Na}^{+}$channels (Chen et al, 1995) but also abolishes dephosphorylation and expression of $\mathrm{IP}_{3} \mathrm{Rs}$ (Genazzani et al, 1999). These findings suggest that chronic COC may suppress $\mathrm{Ca}^{2+}$ signaling via reducing both $I_{\mathrm{Ca}}$ and intracellular released $\mathrm{Ca}^{2+}$, thereby reducing $\mathrm{CaN}$ function and eventually decreasing $I_{\mathrm{Na}}$ in NAc neurons.

An investigation to determine the possible interruption of $\mathrm{Ca}^{2+}$ signaling and the physiological balance between PKA-induced phosphorylation and CaN-induced dephosphorylation of $\mathrm{Na}^{+}$channels after chronic exposure to psychostimulants has recently begun. Besides the increased PKA activity and attenuated $\mathrm{Ca}^{2+}$ signaling after chronic COC treatment (Terwilliger et al, 1991; Zhang et al, 2002; $\mathrm{Hu}$ et al, 2004), the protein levels of DARPP-32 and CaN are also increased and decreased, respectively, after repeated administration of methamphetamine (Lin et al, 2002). Although these changes in PKA activity and $\mathrm{Ca}^{2+}$ signaling appear to be associated with decreased $I_{\mathrm{Na}}$ found in COCwithdrawn NAc neurons, whether and how CaN- and PKAactivated p-Thr.34-DARPP-32 are functionally involved in chronic COC-induced $I_{\mathrm{Na}}$ reduction requires determination.

As the activity of $\mathrm{Na}^{+}$channels is regulated by phosphorylation/dephosphorylation and inhibition of CaN markedly increases the levels of p-Thr.34-DARPP-32 (Nishi et al, 1999b, 2002; Greengard et al, 1999), we hypothesized that both $\mathrm{CaN}$ and p-Thr.34-DARPP-32 modulate chronic COC-induced $I_{\mathrm{Na}}$ reduction. An attenuated $\mathrm{CaN}$ action would be associated with increased DARPP-32 function. Moreover, since PP1 also dephosphorylates $\mathrm{Na}^{+}$channels and is inhibited by p-Thr.34-DARPP-32 (Greengard et al, 1998, 1999; Greengard, 2001), its effects on $I_{\mathrm{Na}}$ were examined concurrently. Voltage-clamp recordings were performed to determine whether $\mathrm{CaN}$ (and PP1) enhances, and p-Thr.34-DARPP-32 suppresses, $I_{\mathrm{Na}}$ in NAc neurons, and whether repeated COC administration alters the effects of CaN, PP1, and p-Thr.34-DARPP-32 on voltage-sensitive sodium currents (VSSCs). Western blot analysis was used to determine whether repeated COC administration alters the protein levels of CaN, PP1, and DARPP-32 in the NAc, and whether the possible changes in the protein levels are correlated with the COC-reduced $I_{\mathrm{Na}}$.

\section{MATERIALS AND METHODS}

\section{Animals and Pretreatments}

Young male Sprague-Dawley rats (Harlan Sprague-Dawley, Indianapolis, IN, USA) at 3-4 weeks of age $(\sim 60 \mathrm{~g})$ were used for pretreatment in all studies. Rats were allowed 3 days to acclimate to the environment. They were group housed (3-4 per cage) in a colony room maintained at constant temperature $\left(21-23^{\circ} \mathrm{C}\right)$ and humidity $(50-65 \%)$ on a 12-h/12-h light/dark cycle and provided access to water and food ad libitum. Rats were given daily injections of COC ( $15 \mathrm{mg} / \mathrm{kg}$ i.p.) or $0.9 \%$ saline ( $1 \mathrm{ml} / \mathrm{kg}$ i.p.) for 5 days in their home cage. NAc tissue was collected after 3 days of withdrawal for the following experiments. After the pretreatment with saline or COC, the age of these rats was approximately 5-6 week old. In electrophysiological experiments, technical limitations usually restrict voltage-clamp recordings in freshly dissociated neurons from rats older than 6 weeks. A prolonged time period for tissue digestion and increased physical force for cell dissociation from older tissues with increased density of fibers could cause damage in dissociated cells that would make the recording extremely difficult.

\section{Preparation of Brain Slices}

All procedures were performed in strict compliance with the National Research Council Guide for the Care and Use of Laboratory Animals (National Research Council, 1996), and were approved by our Institutional Animal Care and Use Committee. Rats were decapitated under halothane anesthesia, and brain tissues containing the NAc were rapidly excised and dissected into blocks. The thickness of brain blocks for cell dissociation was 3-4 mm before slicing, and those reserved for Western blot analysis were cut at $1 \mathrm{~mm}$.

\section{Whole-Cell Voltage-Clamp Recordings}

The blocks of tissues were immersed in ice-cold high sucrose solution (in $\mathrm{mM}: \mathrm{NaCl} 25, \mathrm{KCl} \mathrm{2.5,} \mathrm{HEPES} \mathrm{5,}$ D-glucose 11, sucrose 210, $\mathrm{CaCl}_{2} 2, \mathrm{MgSO}_{4} 2 ; \mathrm{pH}$ value was adjusted to 7.40 with $10 \mathrm{~N}$ and $1 \mathrm{~N} \mathrm{NaOH}$ ) and sectioned in the coronal plane $(350 \mu \mathrm{m})$ with a motorized vibrating microtome. Brain slices were transferred to a stir chamber and incubated in oxygenated $\left(95 \% \quad \mathrm{O}_{2}: 5 \% \mathrm{CO}_{2}\right)$ holding solution (in mM: $\mathrm{NaCl} 126, \mathrm{KCl} 2.5, \mathrm{MgCl}_{2} 2, \mathrm{CaCl}_{2} 2$, $\mathrm{NaH}_{2} \mathrm{PO}_{4}+\mathrm{H}_{2} \mathrm{O} 1.25, \mathrm{NaHCO}_{3} 26$, D-glucose 10, pyruvic acid 1 , phenol red 0.03 ; $\mathrm{pH}$ value was adjusted to 7.20 with $6 \mathrm{~N} \mathrm{HCl}$ at room temperature $\left(20-22^{\circ} \mathrm{C}\right)$ ) for at least $60 \mathrm{~min}$. Slices were then transferred to an oxygen-gassed stir chamber containing protease (Type XIV) in HEPESbuffered HBSS (HEPES: $2.6 \mathrm{~g} / 1 \mathrm{l}$; $\mathrm{pH}$ was adjusted to 7.35 with $10 \mathrm{~N} \mathrm{NaOH} ; 300-310 \mathrm{mOsm} / \mathrm{l})$ at $35^{\circ} \mathrm{C}$ for digestion. After 25-30 min of enzyme digestion, tissues were rinsed three times in the low $\mathrm{Ca}^{2+}$, HEPES-buffered saline (in $\mathrm{mM}$ : $\mathrm{Na}$-isethionate 140, glucose 23, HEPES 15, $\mathrm{KCl} 2, \mathrm{MgCl}_{4} 2$, $\left.\mathrm{CaCl}_{2} \quad 0.01\right)$ and mechanically dissociated with a graded series of fire-polished Pasteur pipettes. The cell suspension was then placed into a Petri dish mounted on the stage of an inverted microscope containing $1 \mathrm{ml}$ HEPES-buffered HBSS. After the cells were allowed to settle, the solution bathing the cell was changed to our normal recording external solution (see below).

Whole-cell recordings using standard voltage-clamp techniques as applied previously in our laboratory (Zhang et al, 1998) were performed in this study. Electrodes were 
pulled from Corning 7056 glass capillaries and fire-polished before use. Sodium current was isolated by using the following solution: internal (pipette solution, in $\mathrm{mM}$ ) $-\mathrm{CsF}$ $120, \mathrm{NaCl} 10, \mathrm{HEPES} \mathrm{10}$, sucrose (to replace EGTA 10), $\mathrm{Na}_{2}$ ATP 2, pH 7.2-7.3 (adjusted with $1 \mathrm{M} \mathrm{CsOH}$ ), 280$285 \mathrm{mOsm} / \mathrm{l}$; external (background solution, in $\mathrm{mM}$ ) - choline choloride $110, \mathrm{NaCl} 30, \mathrm{CsCl} 5, \mathrm{MgCl}_{2}+6 \cdot \mathrm{H}_{2} \mathrm{O} 1, \mathrm{CaCl}_{2}$ 1, $\mathrm{CdCl}_{2}$ 0.4, glucose 10, HEPES 10, pH 7.3-7.4 (adjusted with $5 \mathrm{M} \mathrm{CsOH}), 300-305 \mathrm{mOsm} / \mathrm{l}$. To determine the effects of $\mathrm{Ca}^{2+}$ signaling on modulation of VSSCs, cytosolic-free $\mathrm{Ca}^{2+}$ was preserved in NAc neurons with the absence of $\mathrm{Ca}^{2+}$ chelators in the internal solution. In addition, the relatively low concentration of $\mathrm{NaCl}(30 \mathrm{mM})$ in the external solution was used to minimize voltage-clamp error. Electrodes filled with this solution had a resistance of 1.8$2.5 \mathrm{M} \Omega$ when tested in the bath solution. The junction potential of $-5 \mathrm{mV}$ was measured between the electrode and bath solution and was not compensated. Recordings were obtained with an Axon Instruments 200B patch-clamp amplifier and controlled and monitored with a PC running pCLAMP7 with a $2 \mathrm{kHz}$ filter. Step depolarizing pulses were applied at intervals of 5-10 s to allow enough time for $\mathrm{Na}^{+}$ channels to recover from inactivation. After seal rupture, series resistance $(<10 \mathrm{M} \Omega)$ was compensated $(70-80 \%)$ and periodically monitored. All recorded currents were leaksubtracted. Adequate voltage control was determined by standard methods (Colatsky and Tsien, 1979). Recordings were made only from NAc neurons $(7-15 \mu \mathrm{m}$ somal diameter) that had only a few short proximal dendrites. All experiments were performed at room temperature (20$22^{\circ} \mathrm{C}$ ) since voltage-clamp recordings in freshly dissociated medium spiny (dorsal and ventral) striatal neurons under 'body temperature' $\left(\sim 37^{\circ} \mathrm{C}\right)$ appear to be problematic due to some unrevealed reasons. The numbers of rats used for whole-cell recordings were usually five to eight per each experimental group.

\section{Drug Applications}

Several enzymes and their specific inhibitors were applied either internally or externally to NAc neurons. Preactivated $\mathrm{CaN}$ (recombinant $\mathrm{CaN}-\mathrm{A} \alpha$ and calcineurin $\mathrm{B}$ (CaN-B) coexpressed with yeast myristoyl-CoA:protein $\mathrm{N}$-myristoyltransferase, $100 \mathrm{U})$, PP1 (50 nM), and p-Thr.34DARPP-32 phosphorylated by PKA (200 nM) were dissolved in and internally dialyzed from the pipette solution. The selective CaN inhibitor cyclosporin A (CysA, $200 \mu \mathrm{M}$ ) was externally applied in the bath through a gravity-fed system.

\section{Western Blot Analysis}

Brains from saline- or COC-pretreated rats ( $n=18 /$ group) were rapidly removed from the skull, $1 \mathrm{~mm}$ thick coronal slices were made using a brain matrix, and were dissected on ice. The NAc was collected from slices corresponding to 2.7-1.7 mm anterior to bregma (Paxinos and Watson, 1986). All collected tissue samples were frozen with liquid nitrogen and transferred into $125 \mu \mathrm{l}$ of ice-cold homogenization buffer $(20 \mathrm{mM}$ Tris- $\mathrm{HCl}$ (pH 7.4), 10\% sucrose, $1 \mathrm{mM}$ EDTA, $5 \mathrm{mM}$ EGTA, and protease inhibitors (Roche Diagnostics, Mannheim, Germany)). The samples were then sonicated on ice for three times ( 3 s/each time) and spun down at $14000 \mathrm{~g}$ at $4{ }^{\circ} \mathrm{C}$ for $30 \mathrm{~min}$. The supernatant was collected and used as the soluble fraction. The pellet was resuspended in $50 \mu \mathrm{l}$ of homogenization buffer for analysis and used as the particulate fraction. Tissue samples were not pooled for analysis. All samples were stored at $-80^{\circ} \mathrm{C}$.

After determination of protein content with a modified Lowry assay (Bio-Rad, Hercules, CA), the concentrations of all fractions were adjusted to $1 \mu \mathrm{g}$ protein/ $\mu \mathrm{l}$ using homogenization buffer. At this point, some samples were excluded due to low protein concentration. The samples were mixed with appropriate amounts of $4 \times$ SDS loading buffer (Invitrogen, Carlsbad, CA) and boiled for $5 \mathrm{~min}$ before electrophoresis. Duplicate samples were loaded in quantities of $10 \mu \mathrm{g}$ of total protein for DARPP-32 detection, or $2 \mu \mathrm{g}$ of total protein for all other immunoblotting, and were fractionated using $4-12 \%$ gradient NuPAGE Bis-Tris gels with MOPS electrophoresis buffer (Invitrogen, Carlsbad, CA). The gels were then transferred to Invitrolon PVDF membranes (Invitrogen, Carlsbad, CA). The membranes were blocked for $60 \mathrm{~min}$ with a mixture of $5 \%$ nonfat dry milk and TBS-T (Tris-buffered saline with $0.05 \%$ Tween-20), and then incubated at $4{ }^{\circ} \mathrm{C}$ overnight with specific antibodies diluted in blocking solution. Samples were incubated with goat-anti-DARPP-32 sera (1:500 dilution; Santa Cruz Biotechnology, Santa Cruz, CA) and mouse-anti-actin sera (1:20000 dilution) together in the same solution. Mouse antisera for $\mathrm{CaN}-\mathrm{A}(61 \mathrm{kDa}$, the catalytic subunit of PP2B, which has a CaN-B-binding domain, a CaM-binding domain, and an autoinhibitory domain), CaN-B (19 kDa, the regulatory subunit of PP2B, which has four $\mathrm{Ca}^{2+}$-binding sites, and is bound to CaN-A), PP1 (all from Sigma, St Louis, MO), and actin (Calbiochem, La Jolla, CA) were mixed together in the same incubation solution. Soluble samples were incubated with antibodies diluted to $1: 10000$ for mouse-anti-CaN-A sera, $1: 20000$ for mouse-anti-CaN-B sera, 1:500 for mouse-anti-PP1 sera, and 1:8000 for mouse-anti-actin sera. Particulate samples were incubated with antibodies diluted to $1: 7500$ for mouse-anti-CaN-A sera, 1:15000 for mouse-anti-CaN-B sera, 1:500 for mouse-anti-PP1 sera, and 1:8000 for mouse-anti-actin sera. After the primary incubation, samples were incubated with the appropriate secondary antibodies diluted in blocking solution for $1 \mathrm{~h}$ at room temperature. Immunoreactive bands were visualized with enhanced chemiluminescence (ECL) detection solutions and ECL Hyperfilm (Amersham Biosciences Corp., Piscataway, NJ). Resulting films were scanned with a Scanjet 5400c (Hewlett-Packard, Greeley, CO) and analyzed using Phoretix TotalLab software (Nonlinear Dynamics, Durham, NC). All scanned images were calibrated with a scanned step wedge of known optical densities (Stouffer Graphic Arts, South Bend, IN). In order to adjust for any variations in loading, all detected protein bands were normalized to actin levels. Some data were excluded at this point due to irregularities caused by small air bubbles in the transfer step. Densitometric data from the COC-pretreated group were expressed as a percent change from the saline-treated group. Outlying data points were identified and discarded if they fell outside the range of $2 \mathrm{SD}$ from the mean. 


\section{Statistical Significance}

An unpaired $t$-test was used to estimate the significance of the difference $\left({ }^{*} p<0.05\right.$ and $\left.{ }^{* *} p<0.01\right)$ between saline- and COC-pretreated groups. In addition, comparisons of the CaN- or PP1-induced alterations in $I_{\mathrm{Na}}$ between SAL- and COC-pretreated NAc neurons during a 5 -min period of recording time were made with a two-way analysis of variance (ANOVA) with repeated measures on one variable (time).

\section{RESULTS}

\section{Dephosphorylation of $\mathrm{Na}^{+}$Channels by Exogenous CaN Enhances Whole-Cell $I_{\mathrm{Na}}$ in Freshly Dissociated NAc Neurons}

Freshly dissociated medium spiny NAc neurons without or only with a few short dendritic processes were selected for recording. These neurons exhibited whole-cell capacitance of $3-8 \mathrm{pF}$ as we previously reported (Zhang et al, 1998, 2002). Whole-cell $I_{\mathrm{Na}}$ recordings were elicited by depolarizing pulses from a holding potential of $-70 \mathrm{mV}$. After seal rupture, $\mathrm{Na}^{+}$currents were gradually increased along with the formation of whole-cell configuration. Without influence of any external or internal application of drugs, the peak $\mathrm{Na}^{+}$currents were stabilized within approximately 12 min in NAc neurons of saline-withdrawn rats. However, with internally dialyzed proteins from the recording pipette, the period of time for $I_{\mathrm{Na}}$ stabilization was a few minutes longer. When the basal $I_{\mathrm{Na}}$ was necessarily stabilized, six traces of $I_{\mathrm{Na}}$ were recorded and averaged as the initial control. For all NAc neurons recorded in this study, the initial control $I_{\mathrm{Na}}$ was compared with the altered peak $I_{\mathrm{Na}}$ following continuous application of proteins or drugs. In addition, in a group of control neurons $(n=7)$ from salinepretreated rats, sodium currents were recorded as a basal control for approximately 5-6 $\mathrm{min}$ without application of any drugs (SAL/control) (Figure 1a). In contrast to the response to $\mathrm{CaN}$ (see below), a small change $(<10 \%)$ was observed in the relative current levels during this period of recording time (Figure 1a). Previous studies have demonstrated that $\mathrm{CaN}$ induces a rapid and extensive dephosphorylation of voltage-sensitive $\mathrm{Na}^{+}$channels in neurons of the rat brain via counteracting the effects of cAMPdependent phosphorylation on $\mathrm{Na}^{+}$channel activity (Murphy et al, 1993; Chen et al, 1995). Dephosphorylation of $\mathrm{Na}^{+}$channels by preactivated CaN (PP2B, 100 U) markedly enhanced whole-cell $I_{\mathrm{Na}}$ in medium spiny NAc neurons of saline-pretreated rats (Figure 1a). The CaNinduced $I_{\mathrm{Na}}$ enhancement was completely reversed by bath application of the selective CaN inhibitor CysA $(200 \mu \mathrm{M}$, $n=8 / 8$ cells) (Figure $1 \mathrm{~b}$ ).

\section{Dephosphorylation of $\mathrm{Na}^{+}$Channels by CaN Reverses $I_{\mathrm{Na}}$ Reduction Induced by Repeated COC Pretreatment}

Our previous study has demonstrated that repeated COC administration significantly reduces whole-cell $I_{\mathrm{Na}}$ in medium spiny NAc neurons of rats (Zhang et al, 1998). The COC-induced $I_{\mathrm{Na}}$ reduction in NAc neurons was further investigated in the present study to determine whether it
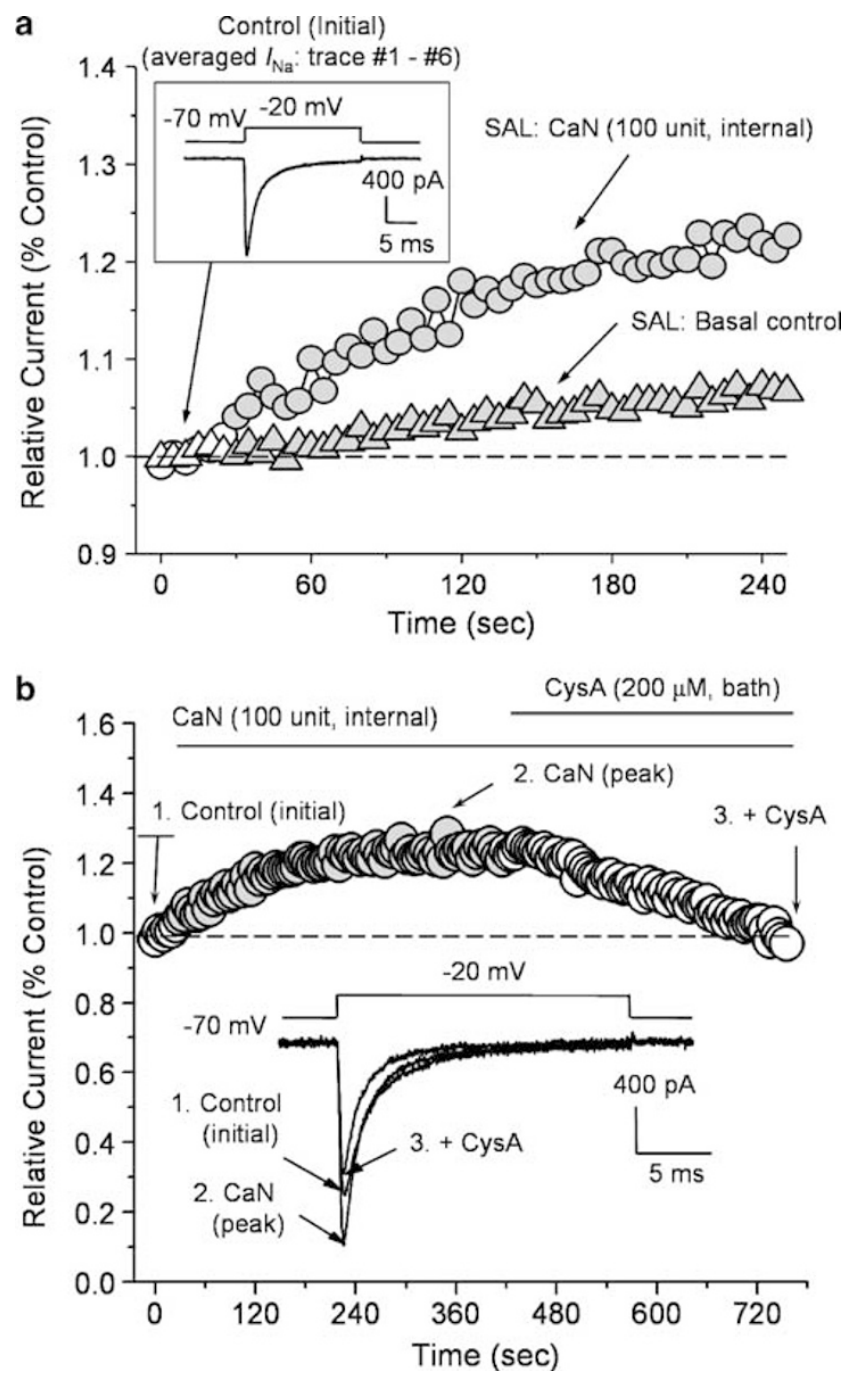

Figure I Dephosphorylation of sodium channels and inhibition of $\mathrm{p}$ Thr.34-DARPP-32 by exogenous CaN (preactivated CaN, PP2B) enhances whole-cell $I_{\mathrm{Na}}$ in freshly dissociated NAc neurons. (a) The time-relative current (\% control) response curves show that cytosolic application of $\mathrm{CaN}$ $(\mathrm{I} 00 \mathrm{U})$ gradually enhanced $I_{\mathrm{Na}}$ in a medium spiny NAc neuron (circle) as compared to another one without $\mathrm{CaN}$ (triangle) recorded in rats after repeated saline pretreatment. The 'open' circles represent the first six relative currents, which were recorded at different time points under a condition in which the $I_{\mathrm{Na}}$ levels were stabilized. These currents were also averaged and used as the initial control (inset) to compare with CaNenhanced $/ \mathrm{Na}$ (the 'solid' circles) at its maximal levels. As a basal control, the relative currents marked with triangles were recorded from a NAc neuron without application of $\mathrm{CaN}$. (b) Representative traces showing that $\mathrm{CaN}$ markedly enhanced $I_{\mathrm{Na}}$, and the $\mathrm{CaN}$-induced $I_{\mathrm{Na}}$ enhancement was completely reversed by bath application of the $\mathrm{CaN}$ inhibitor CysA $(200 \mu \mathrm{M}, n=8 / 8$ cells $)$.

could be reversed via dephosphorylation of $\mathrm{Na}^{+}$channels by CaN. As described above, CaN enhanced $I_{\mathrm{Na}}$ from its initial control levels to an enhanced new peak level in NAc neurons of saline-pretreated rats (Figure 2a, the left traces). In contrast, the initial control levels of $I_{\mathrm{Na}}$ were markedly reduced and the efficacy of $\mathrm{CaN}$ on enhancing $I_{\mathrm{Na}}$ was attenuated in NAc neurons following repeated COC administration (Figure 2a, the right traces). The bar graphs indicate that $\mathrm{CaN}$ induced a significant enhancement in the peak $I_{\mathrm{Na}}$ in NAc neurons of saline-pretreated 


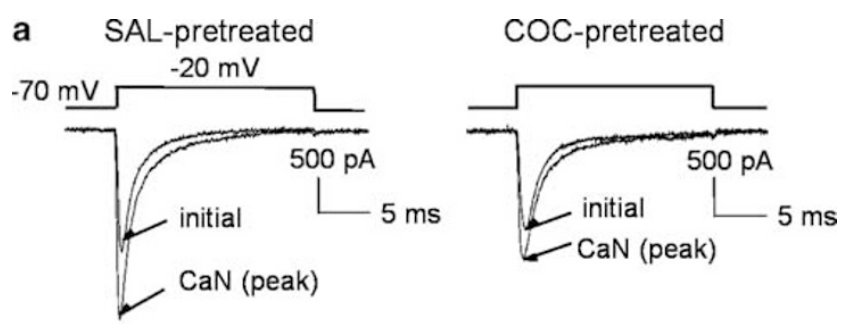

b

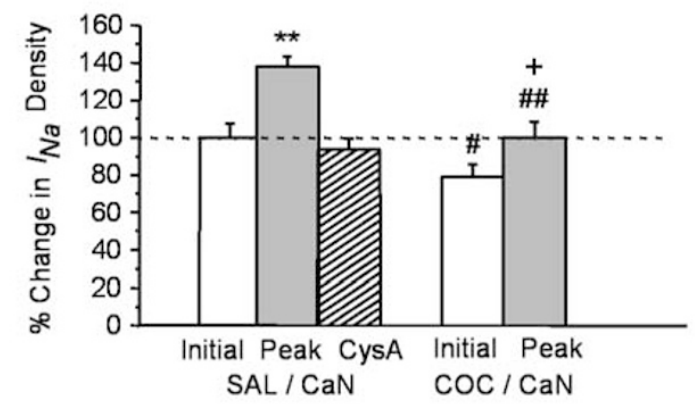

C

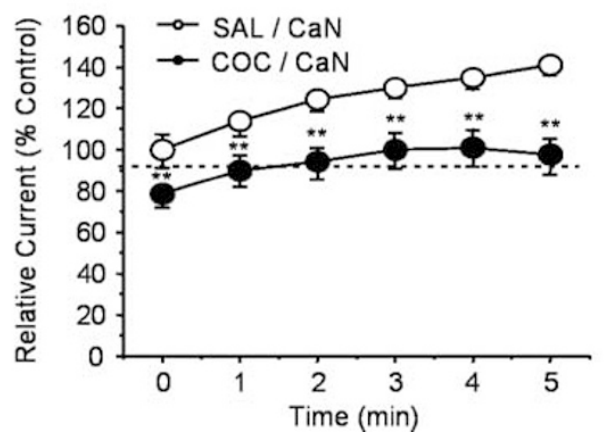

Figure 2 Dephosphorylation of sodium channels and inhibition of $\mathrm{p}$ Thr.34-DARPP-32 by CaN reverses chronic cocaine-induced reduction of $I_{\mathrm{Na}}$. (a) Representative traces showing that $\mathrm{CaN}$ enhanced the $I_{\mathrm{Na}}$ from its initial control levels to a new peak level in a NAc neuron of saline (SAL)pretreated rat. However, the initial control levels of $I_{\mathrm{Na}}$ in NAc cells were markedly reduced in COC-pretreated rats. The efficacy of CaN for enhancing / $/ \mathrm{Na}$ was also attenuated. (b) Bar graphs indicating that $\mathrm{CaN}$ induced enhancement in the peak $I_{\mathrm{Na}}(n=18$ cells, $* * * 0.01)$ was blocked by CysA $(200 \mu \mathrm{M})(n=8$ cells, *** $p<0.01)$. Repeated COC administration significantly reduced peak $/_{\mathrm{Na}}$ in NAc neurons as compared to saline-pretreated control $\left(n=18\right.$ vs 17 cells, $\left.{ }^{*} p<0.05\right)$, but $\mathrm{CaN}$ reversed $\mathrm{COC}$-induced $/ \mathrm{Na}$ reduction to the levels that were comparable to saline-pretreated initial control. Thus, there was a significant $I_{\mathrm{Na}}$ enhancement with application of $\mathrm{CaN}$ in NAc neurons of $\mathrm{COC}$-pretreated rats $\left(n=17\right.$ cells, $\left.{ }^{\# \#} p<0.01\right)$. However, the maximal $/ \mathrm{Na}$ enhancement in $\mathrm{NAc}$ neurons induced by $\mathrm{CaN}$ was significantly lower in COC-pretreated as compared to saline-pretreated rats $\left(n=18\right.$ vs 17 cells, $\left.{ }^{+} p<0.05\right)$. The percent enhancement induced by $\mathrm{CaN}$ was also significantly smaller in COC-pretreated than that in saline-pretreated rats $\left({ }^{+} p<0.05\right)$. (c) The relative current (\% control) curves also indicate that the effects of $\mathrm{CaN}$ on increasing $/_{\mathrm{Na}}$ during a 5 -min recording period were significantly reduced in NAc cells of COC-pretreated rats as compared to saline-pretreated rats (MANOVA, ${ }^{*} p<0.02$; post hoc Neuman-Keuls test, ${ }^{*} p<0.01$ )

rats (SAL/CaN/initial vs SAL/CaN/peak: $248.9 \pm 18.5$ vs $326.3 \pm 28.1 \mathrm{nA} / \mathrm{pF}$; or $100 \pm 7.5$ vs $138.0 \pm 5.6 \%, n=18$ cells, paired $t$-test, $\left.t=5.8273,{ }^{\star *} p<0.01\right)$, which was completely blocked by CysA $(200 \mu \mathrm{M})(\mathrm{SAL} / \mathrm{CaN} /$ peak vs SAL/CaN/ CysA: $326.3 \pm 28.1$ vs $196.6 \pm 16.4 \mathrm{nA} / \mathrm{pF}$, paired $t$-test, $t=11.3854,{ }^{* *} p<0.01$ ) (Figure $2 \mathrm{~b}$ ). Therefore, there was no significant difference in the $I_{\mathrm{Na}}$ between SAL/CaN/initial control and SAL/CaN/CysA.
In contrast, repeated COC administration significantly reduced the peak $I_{\mathrm{Na}}$ in NAc neurons as compared to salinepretreated control (SAL/initial vs COC/initial: $248.9 \pm 18.5$ vs $197.1 \pm 15.7 \mathrm{nA} / \mathrm{pF}, \quad n=18$ vs 17 cells, $t$-test, $t=2.1194$, $\left.{ }^{\#} p<0.05\right)$. Dephosphorylation of $\mathrm{Na}^{+}$channels by cytosolic application of CaN reversed chronic COC-suppressed $I_{\mathrm{Na}}$ to the levels similar to the initial controls observed in salinepretreated rats (COC/initial vs COC/peak: $197.1 \pm 15.7$ vs $248.8 \pm 21.4 \mathrm{nA} / \mathrm{pF}, \quad n=17$ cells, paired $t$-test, $t=7.1132$, ${ }^{\# \#} p<0.01$ ) (Figure $2 \mathrm{~b}$ ). However, the maximal $I_{\mathrm{Na}}$ enhancement in NAc neurons induced by exogenous $\mathrm{CaN}$ was significantly lower in COC-pretreated rats as compared to saline-pretreated rats (COC/CaN/peak vs SAL/CaN/peak: $248.8 \pm 21.4$ vs $326.3 \pm 28.1 \mathrm{nA} / \mathrm{pF}, \quad t$-test, $t=2.214$; or $25.6 \pm 2.6$ vs $38.0 \pm 5.6 \%, t$-test, $t=2.0453, n=18$ vs 17 cells, $\left.{ }^{+} p<0.05\right)$, suggesting that the efficacy of $\mathrm{CaN}$ in modulating dephosphorylation of $\mathrm{Na}^{+}$channels was reduced after repeated COC administration. Normalized relative current curves recorded during a 5-min time course indicate that the effects of $\mathrm{CaN}$ on enhancing $I_{\mathrm{Na}}$ were significantly reduced in NAc neurons of COC-pretreated rats as compared to saline-pretreated rats (MANOVA, $F_{1,33}=6.280,{ }^{*} p<0.02$, post hoc, Neuman-Keuls test, ${ }^{* *} p<0.01$ ) (Figure 2c). These effects of chronic COC on suppressing the function of $\mathrm{Na}^{+}$channels and $\mathrm{CaN}$ are in agreement with that observed in previous current-clamp studies, in which the activities related to VSSCs and voltagesensitive $\mathrm{Ca}^{2+}$ currents (VSCCs) were significantly decreased in more matured rats (8-10 weeks) after repeated COC administration (Zhang et al, 1998; Hu et al, 2004). These findings indicate that chronic COC-induced alterations in ion channel function should not be attributed to the relatively young age of rats.

\section{Dephosphorylation of $\mathrm{Na}^{+}$Channels by PP1 also Reverses Chronic COC-Induced $I_{\mathrm{Na}}$ Reduction}

Previous findings have indicated that $\mathrm{Na}^{+}$channels are also dephosphorylated by other protein phosphatases, including PP1 (Murphy et al, 1993; Chen et al, 1995). Similar to the effects of CaN on $I_{\mathrm{Na}}$, dephosphorylation of $\mathrm{Na}^{+}$channels by cytosolic application of PP1 (50 nM) also increased the peak $I_{\mathrm{Na}}$ in NAc neurons recorded from saline-pretreated rats (Figure 3a, the left traces). Although $I_{\mathrm{Na}}$ was decreased following repeated COC administration, it was also enhanced by exogenous PP1 (Figure 3a, the right traces). The bar graphs indicate that PP1 significantly increased the peak $I_{\mathrm{Na}}$ in NAc neurons of saline-pretreated rats (SAL/PP1/ initial vs SAL/PP1/peak: $295.5 \pm 16$ vs $392.6 \pm 27.1 \mathrm{nA} / \mathrm{pF}$; or $100 \pm 5.4$ vs $133.0 \pm 4.9 \%, n=17$ cells, paired $t$-test, $\left.t=6.2597,{ }^{*} p<0.01\right)$, while repeated COC administration significantly decreased the peak $I_{\mathrm{Na}}$ in NAc neurons (SAL/ initial vs COC/initial: $295.5 \pm 16$ vs $235.2 \pm 21.6 \mathrm{nA} / \mathrm{pF}$, $n=17$ vs $n=17$ cells each, $t$-test, $\left.t=2.2452,{ }^{*} p<0.05\right)$ (Figure $3 \mathrm{~b}$ ). In COC-pretreated rats, however, exogenous PP1 not only reversed the reduction of $I_{\mathrm{Na}}$ in NAc neurons but also enhanced $I_{\mathrm{Na}}$ as it did in saline-pretreated rats (COC/PP1/initial vs COC/PP1/peak: $235.2 \pm 21.6$ vs $364.7 \pm 37.2 \mathrm{nA} / \mathrm{pF}, n=17$ cells, paired $t$-test, $t=6.0838$, $\left.{ }^{\# \#} p<0.01\right)$. The PP1-induced maximal enhancement in $I_{\mathrm{Na}}$ recorded from both groups was comparable, and there was no significant difference in the peak $I_{\mathrm{Na}}$ values between 
saline- and COC-pretreated rats (SAL/PP1/peak vs COC/ PP1/peak, $p>0.05$ ) (Figure 3b). Nevertheless, the percent $I_{\mathrm{Na}}$ enhancement by PP1 was significantly greater in NAc neurons of COC-pretreated rats as compared to salinepretreated rats (SAL/PP1/peak vs COC/PP1/peak: $33.0 \pm 4.9$ vs $\left.56.9 \pm 10 \%, t=2.1098,{ }^{+} p<0.05\right)$. In contrast to the effects of CaN, although cytosolic application of PP1 enhanced $I_{\mathrm{Na}}$ currents in NAc neurons recorded from both saline- and COC-pretreated rats during a 5-min period, there was no significant difference in the relative current curves between saline- and COC-pretreated rats (MANOVA, $F_{1,28}=2.32, p>0.05$ ) (Figure $3 c$ ).

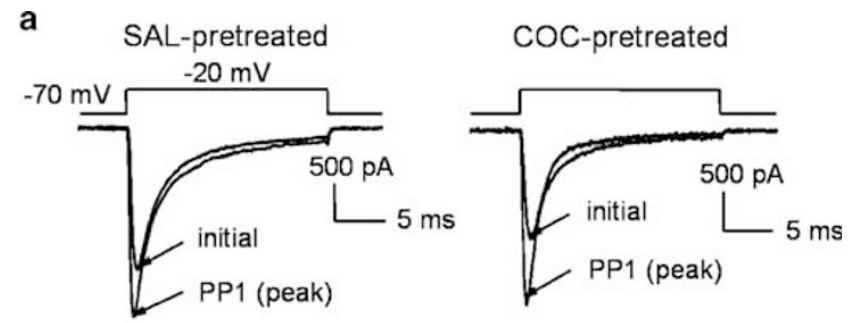

b

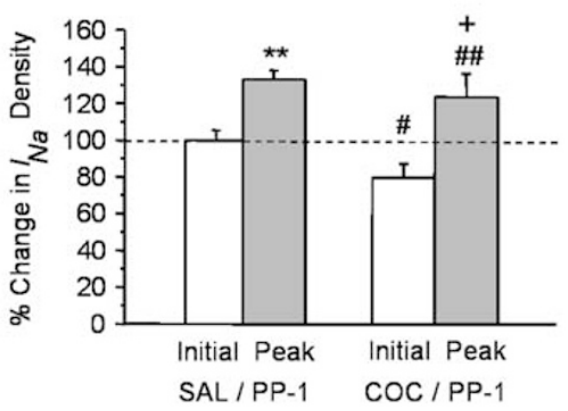

C

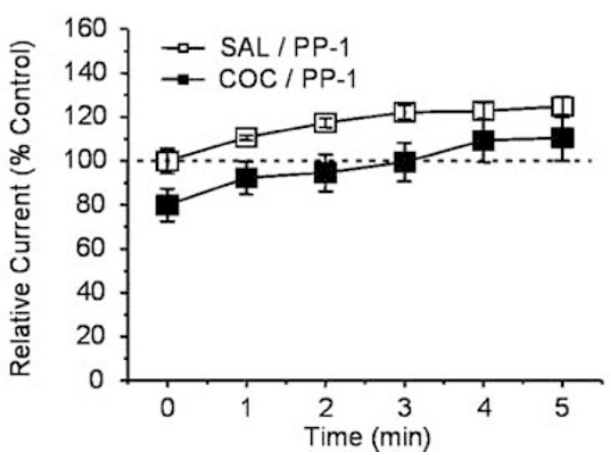

Figure 3 Dephosphorylation of sodium channels by exogenous PPI also reverses chronic COC-induced reduction of $I_{\mathrm{Na}}$. (a) Representative traces showing that cytosolic application of PPI $(50 \mathrm{nM})$ increased whole-cell $I_{\mathrm{Na}}$ in NAc neurons either saline- or COC-pretreated rats. The maximal effects of PPI on enhancing / $\mathrm{Na}$ in NAc neurons were comparable in saline- and COC-pretreated rats. (b) Bar graphs indicating that PPI significantly enhanced peak $I_{\mathrm{Na}}$ in NAc neurons of saline-pretreated rats $(n=17$ cells, *** $p<0.01$ ). Repeated COC administration significantly reduced the peak $I_{\mathrm{Na}}$ as observed previously $\left(n=17 / 17\right.$ cells, $\left.\#_{p}<0.05\right)$. However, exogenous PPI reversed the COC-induced reduction of $I_{\mathrm{Na}}$ to the levels that were comparable to saline-pretreated rats $\left(n=17\right.$ cells, $\left.{ }^{\# \#} p<0.0 I\right)$. Thus, there was no significant difference in the peak $I_{\mathrm{Na}}$ values induced by PPI between saline- and COC-pretreated rats $(p>0.05)$. Nevertheless, the percent enhancement of $/ \mathrm{Na}$ induced by PPI was significantly greater in NAc neurons of COC-pretreated as compared to saline-pretreated rats (SAL/PPI/peak vs COC/PPI/peak: $\left.{ }^{+} p<0.05\right)$. (c) There was no significant difference in the PPI-induced changes in relative current curves between saline- and COC-pretreated NAc rats during a 5-min recording period (MANOVA, $p>0.05$ ).
Inhibition of PP1 by Exogenous DARPP-32 Suppresses $I_{\mathrm{Na}}$ in NAc Neurons of Saline- but not COC-Pretreated Rats

A recent study reveals that $\mathrm{p}$-Thr.34-DARPP-32, a potent inhibitor of PP1, reduces VSSCs in cultured striatal neurons of rats by stabilizing a phosphorylated state of the sodium channel or an associated regulatory protein (Schiffmann et al, 1998). This phenomenon was also observed in the present study. In striking contrast to the effects of $\mathrm{CaN}$ and PP1 on $I_{\mathrm{Na}}$, cytosolic application of p-Thr.34-DARPP-32 $(200 \mathrm{nM})$ markedly suppressed $I_{\mathrm{Na}}$ in NAc neurons of saline-pretreated rats (Figure 4a). It was noted that application of p-Thr.34-DARPP-32 slightly prolonged the period of time that was necessary for stabilizing the peak $I_{\mathrm{Na}}$. Repeated COC administration also caused a marked decrease of $I_{\mathrm{Na}}$ in NAc neurons without exogenous applied p-Thr.34-DARPP-32 (Figure 4a). The $I_{\mathrm{Na}}$ reduction in NAc neurons induced by exogenous p-Thr.34-DARPP-32 in saline-pretreated rats was comparable to that induced by repeated COC administration. However, the suppressing effects of p-Thr.34-DARPP-32 on $I_{\mathrm{Na}}$ observed in salinepretreated rats appeared to be occluded in COC-pretreated rats. The bar graphs indicate that although exogenous $\mathrm{p}$ Thr.34-DARPP-32 significantly reduced $I_{\mathrm{Na}}$ in NAc neurons
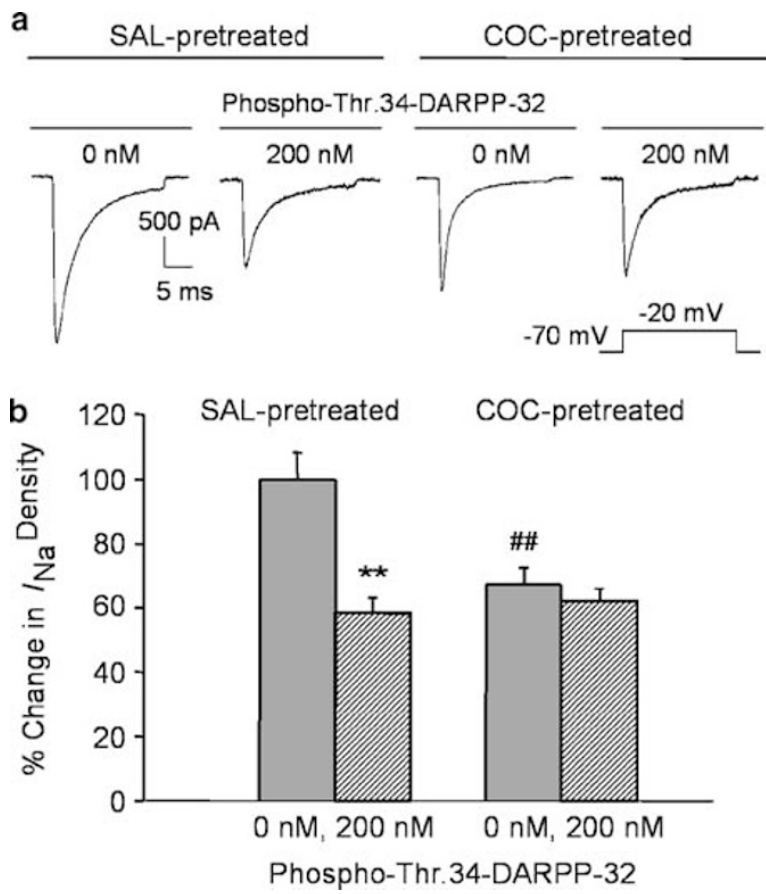

Figure 4 Inhibition of PPI by exogenous p-Thr.34-DARPP-32 suppresses $I_{\mathrm{Na}}$ in NAc neurons of saline- but not COC-pretreated rats. (a) Representative traces showing that internally dialyzed p-Thr.34-DARPP-32 $(200 \mathrm{nM})$ markedly suppressed $I_{\mathrm{Na}}$ in NAc neurons of saline-pretreated rats, while repeated $\mathrm{COC}$ administration mimicked the decreased $I_{\mathrm{Na}}$ in NAc neurons. However, chronic COC-induced $I_{\mathrm{Na}}$ reduction was not potentiated by exogenous p-Thr.34-DARPP-32 (200 nM). (b) Bar graphs indicating that $\mathrm{p}$-Thr.34-DARPP-32 significantly reduced $I_{\mathrm{Na}}$ in NAc neurons of saline-pretreated rats $(n=7 / 15$ cells, $* * * 00.01)$. Although $I_{\mathrm{Na}}$ was also reduced in NAc neurons of COC-pretreated rats in the absence of exogenous p-Thr.34-DARPP-32 $\left(n=7 / 13\right.$, $\left.{ }^{\# \#} p<0.01\right)$, application of exogenous p-Thr.34-DARPP-32 (200 nM) failed to potentiate the effects of repeated COC treatment on $I_{\mathrm{Na}}(n=13 / 8, p>0.05)$. 
of saline-pretreated rats (SAL: 0 vs $200 \mathrm{nM}, 100 \pm 8$ vs $\left.58.5 \pm 4.6 \%, n=7 / 15, t=4.664,{ }^{* *} p<0.01\right)$, and repeated COC pretreatment significantly decreased $I_{\mathrm{Na}}$ in the absence of p-Thr.34-DARPP-32 (SAL:0 vs COC:0 nM, $100 \pm 8$ vs $67.4 \pm 5.2 \%, n=7 / 13, t=3.5646,{ }^{\# \#} p<0.01$ ) (Figure $4 \mathrm{~b}$ ), the reduction of $I_{\mathrm{Na}}$ induced by chronic COC pretreatment was not potentiated by cytosolic application of exogenous p-Thr.34-DARPP-32 (COC: 0 vs $200 \mathrm{nM}, 67.4 \pm 5.2$ vs $62.3 \pm 3.8 \%, n=13 / 8, t=0.6933, p>0.05)$.

\section{Repeated COC Administration Decreases the Levels of CaN but not PP1 in the Rat NAc}

In order to determine whether the alterations in the effects of exogenous CaN, PP1, and DARPP-32 on the $I_{\mathrm{Na}}$ were correlated to the possible changes in the levels of those proteins, Western blot analysis was used to measure the levels of CaN-A $(61 \mathrm{kDa}), \mathrm{CaN}-\mathrm{B}(19 \mathrm{kDa})$, and PP1 $(37.5 \mathrm{kDa})$ within the NAc following repeated saline or $\mathrm{COC}$ administration. Figure 5 indicates the NAc region of the brain from where the tissue samples were collected (shaded area). The proteins were measured in both the soluble and particulate fractions. Probably due to the relatively low concentration of $\mathrm{CaN}$ in the cytosol (up to $70 \%$ of $\mathrm{CaN}$ is bound to the membrane or cytoskeleton elements in neurons; Shibasaki et al, 2002), there was no significant difference in the soluble fractions of $\mathrm{CaN}$, neither CaN-A nor CaN-B, within the NAc of saline- vs COCpretreated rats (CaN-A: SAL vs $\mathrm{COC}=100 \pm 26.69$ vs $93.58 \pm 13.75 \%, n=20 / 20$; CaN-B: SAL vs COC $=100 \pm 30.58$ vs $90.22 \pm 23.96 \%, n=17 / 18$; PP1: SAL vs COC $=100 \pm 9.96$ vs $103.82 \pm 11.56 \%, n=19 / 21$; DARPP-32: SAL vs $\mathrm{COC}=$ $100 \pm 13.44$ vs $93.79 \pm 12.69 \%, \quad n=21 / 22 ; \quad$ all $p>0.05)$ (figures not shown).

However, there was a small but significant decrease (approximately 13-15\%) of $\mathrm{CaN}$ in the particulate fractions obtained from COC-pretreated NAc. Both CaN-A and CaN$B$ immunoreactive bands were significantly reduced in the NAc following repeated COC administration (CaN-A: SAL vs $\mathrm{COC}=100 \pm 5.66$ vs $82.92 \pm 5.08 \%, n=35 / 33 ; t=2.238$,

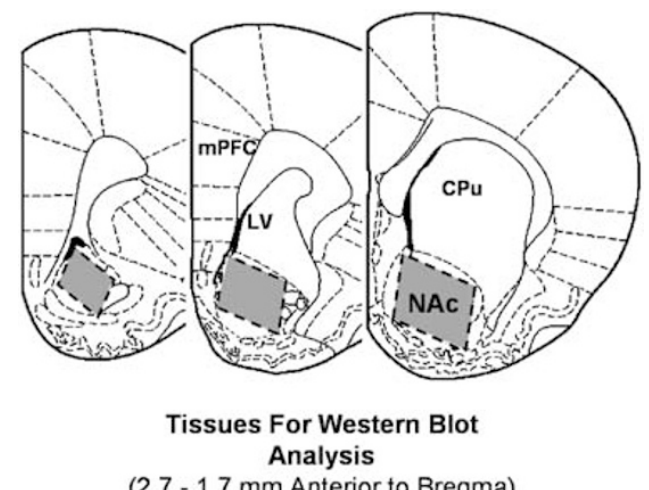

Figure 5 Collection of NAc tissues for Western blot analysis. Brain tissues were collected from the NAc (shadowed areas, 1.7-2.7 mm anterior to the bregma) of saline- and $\mathrm{COC}$-pretreated rats. The protein levels of CaN-A, CaN-B, PPI, and p-Thr.34-DARPP-32 in the NAc were measured by conducting Western blot analysis. NAc: nucleus accumbens; CPu: caudate Putamen; mPFC: medial prefrontal cortex; LV: lateral ventricle.
${ }^{*} p<0.03$; and CaN-B: SAL vs COC $=100 \pm 4.79$ vs $84.87 \pm$ $5.35 \%, n=37 / 38, t=2.105,{ }^{*} p<0.04$ ) (Figure $6 \mathrm{a}$ and $\mathrm{b}$ ). There was, however, no significant change in PP1 immunoreactive bands between NAc tissues obtained from salineand COC-pretreated rats (SAL vs COC: $100 \pm 11.21$ vs $101.73 \pm 9.54 \%, n=27 / 25 ; p>0.05$ ) (Figure $6 \mathrm{~b}$ ). Box plots indicate the alterations in the protein levels with the mean (dashed line), median (solid line), distribution (boxes, indicating the 25 th and 75 th percentiles and showing $50 \%$ of sample distribution), and range ('whiskers', indicating the 10 th and 90th percentiles and showing $80 \%$ of sample distribution) for the levels of $\mathrm{CaN}-\mathrm{A}, \mathrm{CaN}-\mathrm{B}$, and PP1 measured in the NAc of saline- or COC-pretreated rats. The outlying dots indicate the 5 th and 95 th percentiles (showing $90 \%$ of sample distribution).

\section{Repeated COC Administration also Increases the Levels of DARPP-32 in the NAC}

Western blot analysis was also performed to determine the changes in the total protein levels of DARPP-32 in the NAc
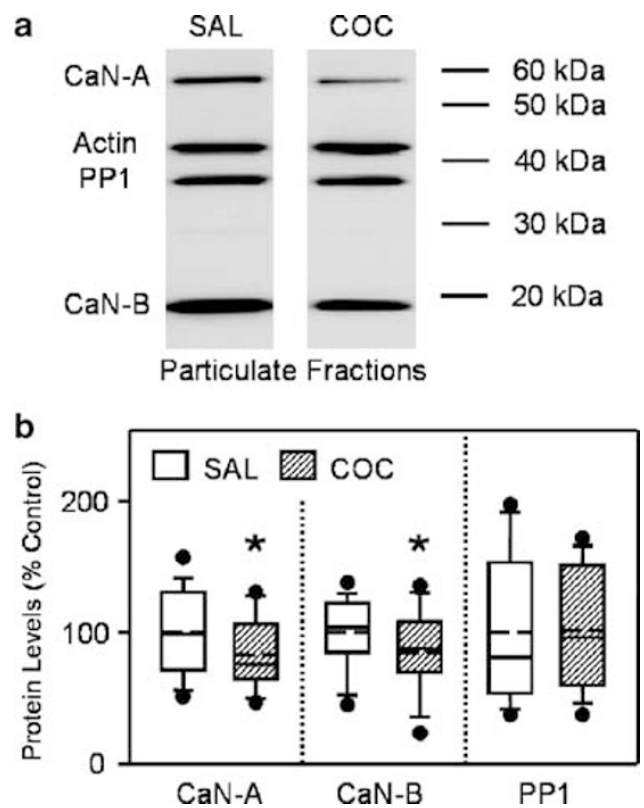

Figure 6 Repeated $\mathrm{COC}$ administration decreases the protein levels of $\mathrm{CaN}$, but not PPI, in the rat NAc. Western blot analysis was used to measure the protein levels of CaN-A ( $61 \mathrm{kDa}), \mathrm{CaN}-\mathrm{B}(19 \mathrm{kDa})$, and PP I $(37.5 \mathrm{kDa})$ in the NAc following repeated saline or COC administration. (a) Representative immunoreactive bands indicating a marked reduction in the levels of both CaN-A and CaN-B. The reduction of protein levels was found only in the particulate, but not the soluble, fractions of $\mathrm{COC}$ pretreated NAc. (b) Box plots indicating that there were significant decreases in the levels of both $\mathrm{CaN}-\mathrm{A}$ and $\mathrm{CaN}-\mathrm{B}$ in the NAc of COCpretreated rats as compared to saline-pretreated rats (CaN-A: SAL vs COC, $n=35 / 33$, * $p<0.03$; CaN-B: SAL vs COC, $n=37 / 38$, $* p<0.04$ ) However, there was no significant difference in the PPI levels between saline- and COC-pretreated rats $(n=15 / 15, p>0.05)$. Box plots showing the mean (dashed line), median (solid line), distribution (boxes, indicating the 25th and 75th percentiles and showing 50\% of sample distribution), and range ('whiskers', indicating the I0th and 90th percentiles and showing $80 \%$ of sample distribution) of the relative protein levels of $\mathrm{CaN}-\mathrm{A}, \mathrm{CaN}-\mathrm{B}$, and PPI measured in the NAc of saline- or COC-pretreated rats. The outlying dots indicate the 5th and 95th percentiles (showing 90\% of sample distribution). 


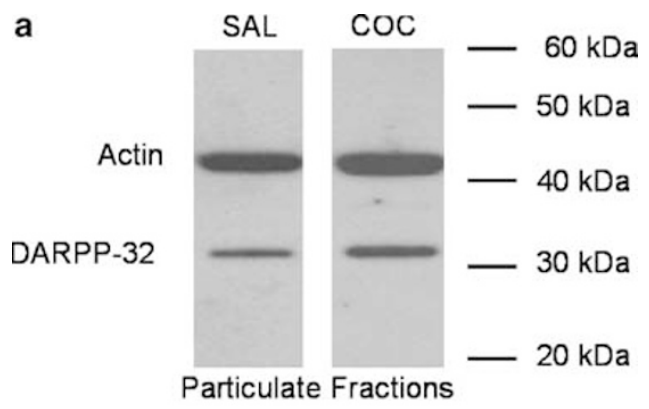

b

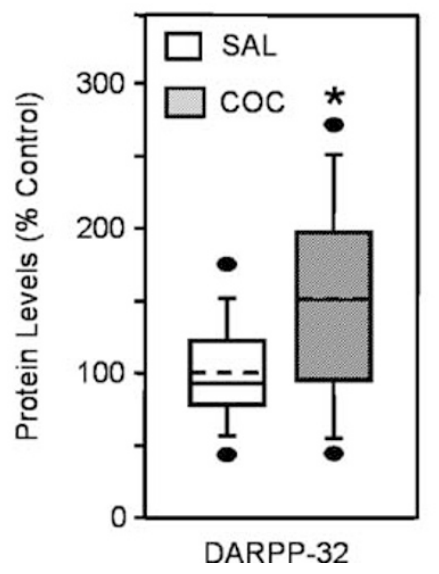

Figure 7 Repeated COC administration increases the levels of DARPP32 in the rat NAc. Western blot analysis was also used to determine the alterations in the protein levels of total DARPP-32 in the NAc following repeated COC administration. (a) Representative immunoreactive bands indicating that in contrast to reduced $\mathrm{CaN}-\mathrm{A}$ and $\mathrm{CaN}-\mathrm{B}$, the levels of total DARPP-32 were increased in the NAc after repeated COC pretreatment. This increase in the DARPP-32 levels was also found in the particulate fractions only. (b) Box plots indicating that there was a significant increase in the levels of total DARPP-32 in the COC-pretreated NAc $(n=15 / 15$, $* p<0.05)$.

after repeated administration of saline or COC. In contrast to the decreased $\mathrm{CaN}$, COC pretreatment significantly increased the levels of total DARPP-32 in the rat NAc. Thus, DARPP-32 immunoreactive bands obtained from the particulate fractions, but not the soluble fractions, of the NAc were significantly increased by approximately $56 \%$ in COC-pretreated rats as compared to saline-pretreated rats (SAL vs COC: $100 \pm 11.31$ vs $156.07 \pm 18.53 \%, n=13 / 17$, $t=2.393,{ }^{\star} p<0.05$ ) (Figure $7 \mathrm{a}$ and $\mathrm{b}$ ).

\section{DISCUSSION}

The present findings indicate that cytosolic application of CaN, PP1, and p-Thr.34-DARPP-32 alters VSSCs in medium spiny NAc neurons of rats. Dephosphorylation of $\mathrm{Na}^{+}$ channels by CaN and PP1 enhances VSSCs, but inhibiting the activity of PP1 with p-Thr.34-DARPP-32 decreases $I_{\mathrm{Na}}$. Repeated COC administration reduces whole-cell $I_{\mathrm{Na}}$ in NAc neurons. This effect of chronic COC on $I_{\mathrm{Na}}$ was associated with a reduction in $\mathrm{CaN}$-induced $I_{\mathrm{Na}}$ enhancement and occlusion of p-Thr.34-DARPP-32-induced suppression of $I_{\mathrm{Na}}$. Moreover, it was also associated with a decrease in the protein levels of $\mathrm{CaN}-\mathrm{A}$ and $\mathrm{CaN}-\mathrm{B}$, but an increase in the levels of DARPP-32, in the COC-withdrawn NAc. Combined

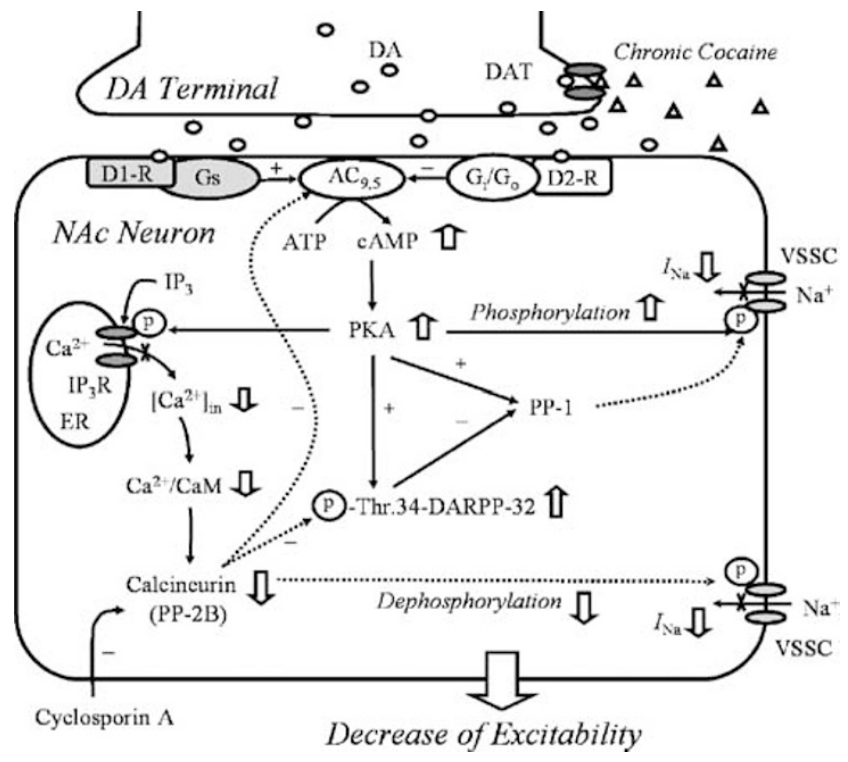

Figure 8 Repeated COC administration suppresses $\mathrm{Na}^{+}$channel function in the NAc: increased phosphorylation by PKA and decreased dephosphorylation by CaN (PP2B). Stimulation of DI- and D2-class DA receptors acts to increase and decrease the activity of the CAMP/PKA cascade, respectively. Phosphorylation of voltage-sensitive $\mathrm{Na}^{+}$channels by PKA decreases $I_{\mathrm{Na}}$, while dephosphorylation of the channel by activated $\mathrm{CaN}$ and PPI increases $I_{\mathrm{Na}}$. CaN also inhibits the activity of $\mathrm{p}$-Thr.34DARPP-32, thereby disinhibiting PPI from suppression of $\mathrm{p}$-Thr.34DARPP-32. Moreover, CaN also regulates the activity of $\mathrm{Ca}^{2+}$-inhibited $\mathrm{AC}_{9,5}$ in NAc neurons. Besides the $\mathrm{Na}^{+}$channel, PKA also phosphorylates the $\mathrm{PP}_{3} \mathrm{R}$, thereby decreasing $\mathrm{Ca}^{2+}$ release, and activates PPI. The solid line/arrows indicate the alterations in the intracellular pathways or ion channel functions mediated by the cAMP/PKA cascade. The dotted lines/ arrows indicate the dephosphorylating effects of $\mathrm{CaN}$ and PPI on their substrates. The sign of ' + ' indicates a stimulatory/active effect, while '-' indicates an inhibitory effect. The 'upward' and 'downward' open arrows indicate an enhanced and decreased response, respectively. Repeated COC administration enhances and prolongs DA action on both DI- and D2-class receptors, leading to an increased DIR but decreased D2R modulation in the cAMP/PKA cascade. The 'open' arrows indicate the COC-induced alterations. Chronic COC-induced increase in PKA activity leads to an enhancement in phosphorylation of $\mathrm{Na}^{+}$channels and $\mathrm{IP}_{3} \mathrm{Rs}$. On the other hand, repeated $\mathrm{COC}$ administration decreases free $\left[\mathrm{Ca}^{2+}\right]_{\text {in }}$ by reducing whole-cell $I_{C a}$ and $I_{3} R$-mediated $\mathrm{Ca}^{2+}$ release, probably via disrupting a reciprocal $\mathrm{Ca}^{+} / \mathrm{IP}^{3} \mathrm{R} / \mathrm{CaN}$ interaction in $\mathrm{Ca}^{2+}$ signaling. As a result, the potency of $\mathrm{CaN}$ in dephosphorylating $\mathrm{Na}^{+}$channels and inhibiting p-Thr.34-DARPP-32 are diminished. However, the mechanism underlying the decreased $\mathrm{CaN}$ levels has not been identified. In addition, the modulatory effects of $\mathrm{CaN}$ on inhibiting $\mathrm{AC}$ activity are also attenuated after chronic COC treatment, which may be related to the increase in DARPP-32 levels. All of these changes result in reduction of VSSCs. The effects of PPI on the activity of $\mathrm{Na}^{+}$channels depend on the combined action of PKA $(+)$ and p-Thr.34-DARPP-32 (-), and is apparently not affected by repeated $\mathrm{COC}$ administration. These findings suggest that the $I_{\mathrm{Na}}$ reduction in COC-withdrawn NAc neurons may be attributed to a suppression in intracellular $\mathrm{Ca}^{2+}$ signaling, which modulates both the increased phosphorylation and decreased dephosphorylation of $\mathrm{Na}^{+}$ channels by PKA and CaN, respectively.

with previous findings, our results suggest that chronic COC-induced $I_{\mathrm{Na}}$ reduction in NAc neurons should be attributed to both an attenuated dephosphorylation and enhanced phosphorylation of $\mathrm{Na}^{+}$channels. The mechanism involved in chronic COC-induced $I_{\mathrm{Na}}$ reduction is summarized in Figure 8. 


\section{Dephosphorylation of $\mathrm{Na}^{+}$Channels by CaN was Reduced after Repeated COC Administration}

It has been proposed that $\mathrm{CaN}$ plays a significant role in regulating VSSCs via $\mathrm{Ca}^{2+}$ signaling (see Introduction). The present study further determines that $\mathrm{CaN}$-induced dephosphorylation facilitates the activity of $\mathrm{Na}^{+}$channels and subsequently increases $I_{\mathrm{Na}}$ in NAc neurons. However, this effect of $\mathrm{CaN}$ on $I_{\mathrm{Na}}$ is disrupted by repeated $\mathrm{COC}$ administration, which decreases the protein levels and diminishes potency of $\mathrm{CaN}$ for dephosphorylation of $\mathrm{Na}^{+}$ channels. The exact mechanism underlying COC-induced attenuation in $\mathrm{CaN}$ activity remains unknown. However, these changes in $\mathrm{CaN}$ activity are likely related to a significant decrease in $\left[\mathrm{Ca}^{2+}\right]_{\mathrm{in}}$, resulting from a reduced VSCCs (Zhang et al, 2002; Hu et al, 2004), and/or a possible disruption of intracellular $\mathrm{Ca}^{2+}$ release. Although an $I_{\mathrm{Na}}$ reduction observed in COC-withdrawn NAc neurons might not be directly linked to decreased $\left[\mathrm{Ca}^{2+}\right]_{\text {in }}$ caused by reduced $I_{\mathrm{Ca}}$ (since VSCCs were blocked during the recording), alterations in a reciprocal interaction among cytosolic-free $\mathrm{Ca}^{2+}, \mathrm{IP}_{3} \mathrm{Rs}$, and $\mathrm{CaN}$ in regulating $\mathrm{IP}_{3} \mathrm{R}$ mediated $\mathrm{Ca}^{2+}$ release should be considered. Previous studies have demonstrated that reduced $\left[\mathrm{Ca}^{2+}\right]_{\text {in }} \mathrm{di}$ minishes the activity of both $\mathrm{CaN}$ and $\mathrm{IP}_{3} \mathrm{Rs}$, while inhibition of $\mathrm{CaN}$ suppresses the dephosphorylation and expression of $\mathrm{IP}_{3} \mathrm{Rs}$ (see Introduction), which could also decrease $\mathrm{Ca}^{2+}$ release and $\left[\mathrm{Ca}^{2+}\right]_{\text {in }}$. In contrast, increased $\left[\mathrm{Ca}^{2+}\right]_{\text {in }}$ activates $\mathrm{CaN}$ and enhances $I_{\mathrm{Na}}(\mathrm{Hu}$ et al, 2005). These findings, combined with the present results, suggest that the reciprocal interaction among $\mathrm{Ca}^{2+} / \mathrm{IP}_{3} \mathrm{R} / \mathrm{CaN}$ in regulating $\mathrm{Ca}^{2+} / \mathrm{CaN}$ signaling and subsequently dephosphorylation of $\mathrm{Na}^{+}$channels are functionally disrupted after repeated COC administration. Thus, a reduced $I_{\mathrm{Na}}$ in COC-withdrawn NAc neurons should be attributed to, at least partially, a decreased $\mathrm{Ca}^{2+}$ signaling.

\section{Phosphorylation of $\mathrm{Na}^{+}$Channels was Increased in COC-Withdrawn NAc Neurons}

The effects of repeated COC administration on suppressing $I_{\mathrm{Na}}$ depend not only on a decreased dephosphorylation of $\mathrm{Na}^{+}$channels by CaN but also on an enhanced phosphorylation of the channel by PKA. Previous studies have determined that repeated COC administration increases the activity of the cAMP/PKA cascade via enhancing the D1Rmediated but decreasing the D2R-mediated signaling, leading to an increase in PKA activity in striatal cells (Terwilliger et al, 1991; Nestler, 1997; Nestler et al, 1990). As PKA-induced phosphorylation of $\mathrm{Na}^{+}$channels decreases $I_{\mathrm{Na}}$ (see Introduction), the chronic COC-induced increase in PKA activity would cause a further reduction in VSSCs as compared to control (Zhang et al, 1998; the present study). Moreover, recent investigations have also demonstrated that PKA activates DARPP-32 by phosphorylating its threonine 34 sites, while $\mathrm{CaN}$ functions as a potent inhibitor of p-Thr.34-DARPP-32 by dephosphorylating those sites (Greengard et al, 1999; Nishi et al, 1997, 1999a; Lindskog et al, 1999). As p-Thr.34-DARPP-32 inhibits PP1 (which stabilizes phosphorylation states of $\mathrm{Na}^{+}$channels) and $\mathrm{CaN}$ is a potent inhibitor of this phosphoprotein (Greengard et al, 1999; Schiffmann et al, 1998), the effect of p-Thr.34-
DARPP-32 on PP1 (and $I_{\mathrm{Na}}$ ) would be attenuated by CaN. In the present study, application of $\mathrm{CaN}$ enhances $I_{\mathrm{Na}}$ in NAc neurons, revealing that a tonic inhibition in the activity of $\mathrm{Na}^{+}$channels by PKA and p-Thr.34-DARPP-32 was diminished following an enhanced dephosphorylation. Furthermore, because inhibition of CaN significantly increases the levels of p-Thr.34-DARPP-32 in striatal neurons (Nishi et al, 1999b, 2002), a marked increase in the levels of DARPP-32 after repeated COC administration could be attributed to, at least partially, a decrease in the CaN levels. Whether the increased levels of total DARPP-32 result from an augmented concentration of p-Thr.34DARPP-32 requires further determination. In addition, an increase in PKA activity after repeated COC administration would also result in an enhanced phosphorylation of $\mathrm{IP}_{3} \mathrm{Rs}$, which might further decrease free $\left[\mathrm{Ca}^{2+}\right]_{\text {in }}$ through reducing $\mathrm{Ca}^{2+}$ release. Given all the above, our findings suggest that the decreased dephosphorylation and increased phosphorylation of $\mathrm{Na}^{+}$channels by CaN and PKA, respectively, plus an enhanced activity of p-Thr.34DARPP-32 in stabilizing the phosphorylation state of the $\mathrm{Na}^{+}$channel, play an integrated and critical role in $I_{\mathrm{Na}}$ reduction in NAc neurons after chronic COC pretreatment.

The observed increase in the levels of DARPP-32 within the COC-withdrawn NAc is similar to that found in behaviorally sensitized rats after repeated treatment with methamphetamine (Lin et al, 2002). These findings suggest a possible common mechanism underlying the increase of DARPP-32 following chronic exposure to psychostimulants. Nevertheless, associated with the increased levels of DARPP-32, the effects of exogenous p-Thr.34-DARPP-32 on suppressing $I_{\mathrm{Na}}$ were occluded in COC-withdrawn NAc cells. Although an $I_{\mathrm{Na}}$ reduction induced by exogenous p-Thr.34-DARPP-32 in NAc neurons of saline-pretreated rats was mimicked by repeated COC treatment, exogenous p-Thr.34-DARPP-32 failed to potentiate the $I_{\mathrm{Na}}$ reduction induced by chronic exposure to COC. These findings suggest that repeated COC administration might have produced a 'ceiling effect' on $\mathrm{p}$-Thr.34-DARPP-32-mediated $I_{\mathrm{Na}}$ reduction, in which the effects of p-Thr.34-DARPP-32 on stabilizing the phosphorylation state of $\mathrm{Na}^{+}$channels had reached (or were near to) their maximal levels.

\section{A Regulatory Effect of CaN on Dephosphorylating Adenylyl Cyclase (AC) may also be Diminished after Chronic Exposure to COC}

Besides a decrease in dephosphorylation of $\mathrm{Na}^{+}$channels and increase in the DARPP-32 levels, a diminished dephosphorylation of AC by CaN should also be considered for $I_{\mathrm{Na}}$ reduction in $\mathrm{COC}$-withdrawn cells. It is well known that there are at least nine different isotypes of $\mathrm{AC}\left(\mathrm{AC}_{1-9}\right)$, which are broadly subclassified into $\mathrm{Ca}^{2+}$-stimulated, $\mathrm{Ca}^{2+}$ -inhibited, and protein kinase C-activated ACs (Antoni et al, 1998a, b; Simonds, 1999). The activity of $\mathrm{Ca}^{2+}$-inhibited ACs is regulated by free $\mathrm{Ca}^{2+}$ and $\mathrm{CaN}$, through which the cAMP signal is dynamically tuned. For instance, the activity of $\mathrm{AC}_{9}$, the most abundant cerebral $\mathrm{AC}$ at the mRNA level (Paterson et al, 1995; Premont et al, 1996), is inhibited by $\mathrm{Ca}^{2+}$ and this effect of $\mathrm{Ca}^{2+}$ on $\mathrm{AC}_{9}$ is blocked selectively by inhibition of CaN (Antoni et al, 1998a, b). Moreover, significant levels of $\mathrm{AC}_{5}$, another $\mathrm{Ca}^{2+}$-inhibited $\mathrm{AC}$, are 
found only in the striatum and the mesolimbic DA system (Glatt and Snyder, 1993; Mons and Cooper, 1995). These findings indicate that the $\mathrm{Ca}^{2+}$-inhibited $\mathrm{AC}$ is predominant in medium spiny neurons within the dorsal and ventral striatum of rats. Based on these findings, we propose that a decrease in the CaN activity after repeated COC administration would result in a disinhibition (increase) in the function of $\mathrm{Ca}^{2+}$-inhibited $\mathrm{AC}_{9,5}$ and PKA, thereby facilitating phosphorylation of $\mathrm{Na}^{+}$channels by PKA, which also leads to a reduction in $I_{\mathrm{Na}}$.

Although the increase in $I_{\mathrm{Na}}$ has been associated with the inhibitory effects of $\mathrm{Ca}^{2+} / \mathrm{CaN}$ on $\mathrm{AC}$, it is noted that inhibition of PKA by fluoride $\left(\mathrm{F}^{-}\right)$(Vargas et al, 1999), a component of the internal solution commonly used in previous voltage-clamp recordings, may also play a role in this event. However, we have determined that the $\mathrm{F}^{-}$-induced changes in $I_{\mathrm{Na}}$ during a 5-6 min period of recording time were insignificant (usually $<10 \%$ ) as compared to that induced by either a relatively high concentration of cytosolic-free $\mathrm{Ca}^{2+}$ (Hu et al, 2005) or internally applied CaN. Moreover, we also found that $I_{\mathrm{Na}}$ enhancement induced by $\mathrm{Ca}^{2+}$ and $\mathrm{CaN}$ was more rapid (2$4 \mathrm{~min}$ ) than that in control cells, which might be affected by $\mathrm{F}^{-}$. These findings are apparently in agreement with the study of Vargas et al (1999), and therefore suggest that, during a relatively short period of treatment time, fluorideinduced inhibition in PKA activity may not have a significant impact in $\mathrm{Ca}^{2+} / \mathrm{CaN}$-modulated $I_{\mathrm{Na}}$ enhancement in rat NAc neurons.

\section{Dephosphorylating Effects of PP1 on $I_{\mathrm{Na}}$ was not Affected Following COC Withdrawal}

In contrast to $\mathrm{CaN}$ and p-Thr.34-DARPP-32, the maximal effects of PP1 on regulating $I_{\mathrm{Na}}$ and the protein levels of PP1 appeared to be unchanged in COC-withdrawn NAc neurons. These results, particularly the unchanged effects of PP1 on $I_{\mathrm{Na}}$, were not expected since p-Thr.34-DARPP-32 is a potent PP1 inhibitor (Bibb et al, 1999; Greengard et al, 1999), and the levels of DARPP-32 were significantly increased in COC-withdrawn NAc neurons. The underlying mechanism regarding this phenomenon is unknown. However, earlier studies have proposed that PP1 is activated by PKA in striatal neurons (Surmeier et al, 1995). It is possible that the increased inhibitory effects of p-Thr.34-DARPP-32 on PP1 were associated with and compensated by enhanced activation of PP1 induced by PKA. Therefore, no significant changes in $I_{\mathrm{Na}}$ could be detected in response to applied PP1 in COC-withdrawn NAc neurons.

\section{Functional Implications}

Our novel findings indicate that both CaN and PP1 enhance whole-cell VSSCs, but p-Thr.34-DARPP-32 reduces $I_{\mathrm{Na}}$ in NAc neurons of rats. They also suggest that chronic COCinduced $I_{\mathrm{Na}}$ reduction should be attributed to both the increased phosphorylation and decreased dephosphorylation of sodium channels by PKA and CaN, respectively. More importantly, our findings reveal that the chronic COC-induced alterations in the intracellular signal transduction are not only limited in the cAMP/PKA cascade but also in the $\mathrm{Ca}^{2+}$ signaling, including the $\mathrm{Ca}^{2+}$ signaling- related proteins. A reduction in $I_{\mathrm{Na}}$ (and $I_{\mathrm{Ca}}$ ) decreases the membrane excitability and reduces the ability of NAc neurons to relay essential cognitive and motivational commands to their target neurons. This disconnection (or attenuated connection) may contribute to the mechanism underlying the addiction and withdrawal effects of COC. Taken together, the global depression in the neuronal activity is likely to disrupt the ability of the NAc to integrate motivational and reward-associated learning processes and this could contribute to the pathophysiology of drug addiction.

\section{ACKNOWLEDGEMENTS}

We acknowledge Carolyn Grevers for her excellent technical assistance. We also thank Drs Pastor P Couceyro, Ann K Snyder, and Judy Potashkin for their helpful suggestions in Western blot analysis. This study was supported by USPHS Grant DA-04093 and Research Scientist Development Award DA 00456.

\section{REFERENCES}

Antoni FA, Palkovits M, Simpson J, Smith SM, Leitch AL, Rosie R et al (1998a). $\mathrm{Ca}^{2+} /$ calcineurin-inhibited adenylyl cyclase, highly abundant in forebrain regions, is important for learning and memory. J Neurosci 18: 9650-9661.

Antoni FA, Smith SM, Simpson J, Rosie R, Fink G, Paterson JM (1998b). Calcium control of adenylyl cyclase: the calcineurin connection. Adv Second Messenger Phosphoprotein Res 32: $153-172$

Bibb JA, Snyder GL, Nishi A, Yan Z, Meijer L, Fienberg AA et al (1999). Phosphorylation of DARPP-32 by Cdk5 modulates dopamine signalling in neurons. Nature 402: 669-671.

Cameron AM, Nucifora Jr FC, Fung ET, Livingston DJ, Aldape RA, Ross CA et al (1997). FKBP12 binds the inositol 1,4,5-trisphosphate receptor at leucine-proline (1400-1401) and anchors calcineurin to this FK506-like domain. J Biol Chem 272: 27582-27588.

Cameron AM, Steiner JP, Roskams AJ, Ali SM, Ronnett GV, Snyder $\mathrm{SH}$ (1995). Calcineurin associated with the inositol 1,4,5trisphosphate receptor-FKBP12 complex modulates $\mathrm{Ca}^{2+}$ flux. Cell 83: 463-472.

Cantrell AR, Scheuer T, Catterall WA (1999). Voltage-dependent neuromodulation of $\mathrm{Na}^{+}$channels by $\mathrm{D}_{1}$-like dopamine receptors in rat hippocampal neurons. J Neurosci 19: 5301-5310.

Catterall WA (1997). Modulation of sodium and calcium channels by protein phosphorylation and $\mathrm{G}$ proteins. Adv Second Messenger Phosphoprotein Res 31: 159-181.

Chen TC, Law B, Kondratyuk T, Rossie S (1995). Identification of soluble protein phosphatases that dephosphorylate voltage-sensitive sodium channels in rat brain. J Biol Chem 270: 7750-7756.

Colatsky TJ, Tsien RW (1979). Sodium channels in rabbit cardiac Purkinje fibres. Nature 278: 265-268.

Ferris CD, Cameron AM, Bredt DS, Huganir RL, Snyder SH (1991). Inositol 1,4,5-trisphosphate receptor is phosphorylated by cyclic AMP-dependent protein kinase at serines 1755 and 1589. Biochem Biophys Res Commun 175: 192-198.

Genazzani AA, Carafoli E, Guerini D (1999). Calcineurin controls inositol 1,4,5-trisphosphate type 1 receptor expression in neurons. Proc Natl Acad Sci USA 96: 5797-5801.

Glatt CE, Snyder SH (1993). Cloning and expression of an adenylyl cyclase localized to the corpus striatum [see comments]. Nature 361: 536-538. 
Greengard P (2001). The neurobiology of dopamine signaling. Biosci Rep 21: 247-269.

Greengard P, Allen PB, Nairn AC (1999). Beyond the dopamine receptor: the DARPP-32/protein phosphatase-1 cascade. Neuron 23: $435-447$.

Greengard P, Nairn AC, Girault JA, Ouimet CC, Snyder GL, Fisone $\mathrm{G}$ et al (1998). The DARPP-32/protein phosphatase-1 cascade: a model for signal integration. Brain Res Brain Res Rev 26: 274-284.

Herzig S, Neumann J (2000). Effects of serine/threonine protein phosphatases on ion channels in excitable membranes. Physiol Rev 80: 173-210.

Hu X-T, Basu S, White FJ (2004). Repeated cocaine administration suppresses $\mathrm{HVA}-\mathrm{Ca}^{2+}$ potentials and enhances activity of $\mathrm{K}^{+}$ channels in rat nucleus accumbens neurons. J Neurophysiol 92: 1597-1608.

Hu X-T, Yan D, Zhang X-F, White FJ (2005). Dopamine $\mathrm{D}_{2}$ receptor-activated $\mathrm{Ca}^{2+}$ signaling modulates voltage-sensitive sodium currents in rat nucleus accumbens neurons. J Neurophysiol (in press).

Hyman SE (1996). Addiction to cocaine and amphetamine. Neuron 16: 901-904.

Li M, West JW, Lai Y, Scheuer T, Catterall A (1992). Functional modulation of brain sodium channels by cAMP-dependent phosphorylation. Neuron 8: 1151-1159.

Lin X-H, Hashimoto T, Kitamura N, Murakami N, Shirakawa O, Maeda K (2002). Decreased calcineurin and increased phosphothreonine-DARPP-32 in the striatum of rats behaviorally sensitized to methamphetamine. Synapse 44: 181-187.

Lindskog M, Svenningsson P, Fredholm BB, Greengard P, Fisone G (1999). Activation of dopamine $D_{2}$ receptors decreases DARPP32 phosphorylation in striatonigral and striatopallidal projection neurons via different mechanisms. Neuroscience 88: 1005-1008.

Mons N, Cooper DM (1995). Adenylate cyclases: critical foci in neuronal signaling. Trends Neurosci 18: 536-542.

Murphy BJ, Rossie S, De Jongh KS, Catterall WA (1993). Identification of the sites of selective phosphorylation and dephosphorylation of the rat brain $\mathrm{Na}^{+}$channel alpha subunit by cAMP-dependent protein kinase and phosphoprotein phosphatases. J Biol Chem 268: 27355-27362.

National Research Council (1996). Guide for the Care and Use of Laboratory Animals. National Academy Press: Washington, DC.

Nestler EJ (1997). Molecular mechanisms of opiate and cocaine addiction. Curr Opin Neurobiol 7: 713-719.

Nestler EJ, Terwilliger RZ, Walker JR, Sevarino KA, Duman RS (1990). Chronic cocaine treatment decreases levels of the $G$ protein subunits $G_{i \alpha}$ and $G_{o \alpha}$ in discrete regions of rat brain. J Neurochem 55: 1079-1082.

Nishi A, Bibb JA, Matsuyama S, Hamada M, Higashi H, Nairn AC et al (2002). Regulation of DARPP-32 dephosphorylation at PKA- and Cdk5-sites by NMDA and AMPA receptors: distinct roles of calcineurin and protein phosphatase-2A. J Neurochem 81: 832-841.

Nishi A, Snyder GL, Fienberg AA, Fisone G, Aperia A, Naim AC et al (1999a). Requirement for DARPP-32 in mediating effect of dopamine $\mathrm{D}_{2}$ receptor activation. Eur J Neurosci 11: 2589-2592.

Nishi A, Snyder GL, Greengard P (1997). Bidirectional regulation of DARPP-32 phosphorylation by dopamine. J Neurosci 17: 8147-8155.

Nishi A, Snyder GL, Nairn AC, Greengard P (1999b). Role of calcineurin and protein phosphatase- $2 \mathrm{~A}$ in the regulation of DARPP-32 dephosphorylation in neostriatal neurons. J Neurochem 72: 2015-2021.
Paterson JM, Smith SM, Harmar AJ, Antoni FA (1995). Control of a novel adenylyl cyclase by calcineurin. Biochem Biophys Res Commun 214: 1000-1008.

Paxinos G, Watson C (1986). The Rat Brain in Stereotaxic Coordinates. Academic Press: Sydney.

Premont RT, Matsuoka I, Mattei MG, Pouille Y, Defer N, Hanoune J (1996). Identification and characterization of a widely expressed form of adenylyl cyclase. J Biol Chem 271: 13900-13907.

Quinton TM, Dean WL (1992). Cyclic AMP-dependent phosphorylation of the inositol-1,4,5-trisphosphate receptor inhibits $\mathrm{Ca}^{2+}$ release from platelet membranes. Biochem Biophys Res Commun 184: 893-899.

Schiffmann SN, Desdouits F, Menu R, Greengard P, Vincent JD, Vanderhaeghen JJ et al (1998). Modulation of the voltage-gated sodium current in rat striatal neurons by DARPP-32, an inhibitor of protein phosphatase. Eur J Neurosci 10: 1312-1320.

Shibasaki F, Hallin U, Uchino H (2002). Calcineurin as a multifunctional regulator. J Biochem (Tokyo) 131: 1-15.

Simonds WF (1999). G protein regulation of adenylate cyclase. Trends Pharmacol Sci 20: 66-73.

Smith RD, Goldin AL (1997). Phosphorylation at a single site in the rat brain sodium channel is necessary and sufficient for current reduction by protein kinase A. J Neurosci 17: 6086-6093.

Supattapone S, Danoff SK, Theibert A, Joseph SK, Steiner J, Snyder SH (1988). Cyclic AMP-dependent phosphorylation of a brain inositol trisphosphate receptor decreases its release of calcium. Proc Natl Acad Sci USA 85: 8747-8750.

Surmeier DJ, Bargas J, Hemmings Jr HC, Nairn AC, Greengard P (1995). Modulation of calcium currents by a D1 dopaminergic protein kinase/phosphatase cascade in rat neostriatal neurons. Neuron 14: 385-397.

Tang TS, Tu H, Wang Z, Bezprozvanny I (2003). Modulation of type 1 inositol $(1,4,5)$-trisphosphate receptor function by protein kinase A and protein phosphatase 1alpha. J Neurosci 23: 403-415.

Tertyshnikova S, Fein A (1998). Inhibition of inositol 1,4,5trisphosphate-induced $\mathrm{Ca}^{2+}$ release by cAMP-dependent protein kinase in a living cell. Proc Natl Acad Sci USA 95: 1613-1617.

Terwilliger R, Beitner-Johnson D, Sevarino KA, Crain SM, Nestler EJ (1991). A general role for adaptations in G-proteins and the cyclic AMP system in mediating the chronic actions of morphine and cocaine on neuronal function. Brain Res 548: 100-110.

Vargas G, Yeh TY, Blumenthal DK, Lucero MT (1999). Common components of patch-clamp internal recording solutions can significantly affect protein kinase A activity. Brain Res $\mathbf{8 2 8}$ 169-173.

Volpe P, Alderson-Lang BH (1990). Regulation of inositol 1,4, 5-trisphosphate-induced $\mathrm{Ca}^{2+}$ release. II. Effect of cAMPdependent protein kinase. Am J Physiol 258: C1086-C1091.

White FJ, Kalivas PW (1998). Neuroadaptations involved in amphetamine and cocaine addiction. Drug Alcohol Depend 51: 141-153.

Yakel JL (1997). Calcineurin regulation of synaptic function: from ion channels to transmitter release and gene transcription. Trends Pharmacol Sci 18: 124-134.

Zhang XF, Cooper DC, White FJ (2002). Repeated cocaine treatment decreases whole-cell calcium current in rat nucleus accumbens neurons. J Pharmacol Exp Ther 301: 1119-1125.

Zhang X-F, Hu X-T, White FJ (1998). Whole-cell plasticity in cocaine withdrawal:reduced sodium currents in nucleus accumbens neurons. J Neurosci 18: 488-498. 